\author{
Alicja GĘBCZYŃSKA ${ }^{1}$ \\ Andrzej BUJAK ${ }^{2}$
}

\title{
WYKORZYSTANIE PROGRAMU ADOSCORE W OBSZARZE WSPOMAGANIA PODEJMOWANIA DECYZJI I KSZTALTOWANIA STRATEGII ORGANIZACJI
}

\begin{abstract}
Niestabilność otoczenia wymaga ciągłego rozwoju organizacji zgodnego z oczekiwaniami klientów i innych interesariuszy. Przyjęty kierunek rozwoju musi być spójny z wizją organizacji, a jego odzwierciedleniem powinna być strategia przedsiębiorstwa, zawierająca cele i działania sprzyjające osiągnięciu sukcesu. Wdrożenie i pomiar realizacji strategii powodują potrzebę wykorzystania metodologii wspierającej jej implementację, przy czym skuteczność wdrożenia strategii zależy od umiejętności wykorzystania dostępnych technik informatycznych. Powyższy zapis był przesłanką do analizy programu ADOscore w zakresie identyfikacji jego potencjalnych korzyści w obszarze wspomagania podejmowania decyzji i kształtowania strategii. W tym celu w początkowej części artykułu przybliżono istotę strategii, odwołując się do złożoności procesu jej implementacji oraz ograniczeń blokujących realizację strategii. Następnie opisano złożenia i idę jednej z metod umożliwiających wdrożenie strategii. W tym celu wybrano strategiczną kartę wyników ponieważ bazuje na niej program ADOscore. W dalszej cześć artykułu scharakteryzowano analizowany program, szczególną uwagę poświęcając praktycznym możliwościom jego zastosowania, prezentując przykładowe modele. Przybliżenie programu i analiza jego funkcjonalności pozwoliły na zidentyfikowanie jego zalet $\mathrm{w}$ obszarze podejmowania decyzji i kształtowania strategii. Stwierdzono, że do głównych korzyści wynikających z zastosowania programu ADOscore należy zaliczyć transponowanie założeń strategicznych na poziom celów strategicznych i operacyjnych, wraz z możnością bieżącego ich monitorowania. Zwieńczeniem artykułu jest podsumowanie zawierające najważniejsze implikacje wynikające z podjętych rozważań.
\end{abstract}

Slowa kluczowe: program ADOscore, strategia, Zrównoważona Karta Wyników, zalety programu, zarządzanie strategiczne, misja organizacji.

\section{WPROWADZENIE}

Ilość i złożoność informacji oraz potrzeba ich przetworzenia i wykorzystania wiążą się z koniecznością wprowadzenia technologii informatycznych. Dostępność danych, na podstawie których podejmowane są decyzje zarządcze, ma kluczowe znaczenie dla sprawności i skuteczności działania przedsiębiorstwa. Prawidłowa komunikacja i sprawny przepływ informacji to podstawa istnienia i rozwoju współczesnych firm. Prawidłowość

\footnotetext{
${ }^{1}$ Dr inż. Alicja Gębczyńska, Wydział Finansów i Zarządzania, Wyższa Szkoła Bankowa we Wrocławiu, ul. Fabryczna 29-31, 53-609 Wrocław, alicja.gebczynska@wsb.wroclaw.pl

${ }^{2}$ Dr hab. inż. Andrzej Bujak, Wydział Finansów i Zarządzania, Wyższa Szkoła Bankowa we Wrocławiu, ul. Fabryczna 29-31, 53-609 Wrocław, andrzej.bujak@wsb.wroclaw.pl
} 
ta ma również zastosowanie w obszarze kształtowania strategii organizacji. Wdrażanie strategii jest skomplikowanym i pracochłonnym procesem wymagającym wiedzy, doświadczenia i umiejętności planowania oraz kontrolowania celów organizacji. Złożoność wdrażania strategii organizacji, jak również konieczność jej implementacji na różnych poziomach zarządczych wymaga skorzystania ze wsparcia informatycznego, w postaci odpowiedniego oprogramowania. W tym zakresie zastosowanie znajduje system ADOscore oferujący całościowe wsparcie informatyczne dla efektywnego zaprojektowania oraz wdrożenia strategicznej karty wyników oraz systemu zarządzania wydajnością organizacji (Corporate Performance Management). W związku z powyższym celem artykułu jest wskazanie możliwości programu ADOscore w obszarze wspomagania podejmowania decyzji i kształtowania strategii organizacji.

„Pojęcie strategii należy utożsamiać z długofalową koncepcją rozwoju określającą cele i sposoby ich realizacji”, ., Strategie można utożsamiać z planem działania, przygotowanym na wszystkich poziomach konfiguracji systemu zarządzania strategicznego"4. „Zgodnie z Andrewsem strategia jest zbiorem celów (zadań) ujętych w programy i plany, stanowi wzorzec decyzji, które dotyczą pozycji i tożsamości przedsiębiorstwa, jego zdolności do wykorzystania swoich mocnych stron oraz prawdopodobieństwa odniesienia sukcesu na rynku"5.

Długotrwałe i efektywne funkcjonowanie każdego przedsiębiorstwa na wymagającym rynku, wiąże się z przyjęciem priorytetów dotyczących rozwoju organizacji, które powinny znaleźć odzwierciedlenie w strategii działania. Strategia jest swoistym wzorcem działania, wytyczającym cele, zadania i standardy realizacji w odniesieniu do struktur, procesów i zachowań.

Każda strategia wymaga zaprojektowania, a następnie wdrożenia. Faza wdrożeniowa jest najbardziej problematyczna i sprawia najwięcej trudności, wynikających z pojawiających się wątpliwości, będących konsekwencją złożoności zagadnienia. Osiągnięcie sukcesu we wdrażaniu strategii jest szczególnie trudne w praktyce ${ }^{6}$. „Klasycznie około połowy pomysłów zapisanych $\mathrm{w}$ planach strategicznych nigdy nie zobaczy światła dziennego"7. Najnowsze wyniki badań ${ }^{8}$ potwierdzają tezę o problemach z wprowadzaniem zmian, tylko niecałe $30 \%$ badanych organizacji osiągnęło w pełni zakładane cele.

Wśród najważniejszych przeszkód skutecznej realizacji strategii organizacji pojawia się problem z przekazywaniem strategii na niższe poziomy organizacyjne ${ }^{9}$. „Jak wynika z badań, aż 80\% kadry zarządzającej deklaruje posiadanie odpowiedniej strategii, ale

\footnotetext{
3 A. Kaleta, Realizacja strategii, Wrocław 2013.

${ }^{4}$ A. Stabryła, Zarzadzanie strategiczne w teorii i praktyce firmy, Warszawa-Kraków 2002.

${ }^{5}$ G. Gierszewska, B. Olszewska, J. Skonieczny, Zarzq̨dzanie strategiczne dla inżynierów, Warszawa 2013.

${ }^{6}$ T. Cater, D. Pucko, Factors of effective strategy implementation: empirical evidence from Slovenian business practice. J East Eur Manag Stud 15(3), 2010, http://www.jstor.org/stable/23281679 (dostęp: 09.11.2015 r.).

${ }^{7}$ R. Burlton, Delivery Business Strategy Through Process Management, Handbook on Business Process Management 2. Strategic Alignment, Governance, People and Culture 2015, http://www.springer.com/978-3-642-45102-7 (dostęp: 12.10.2015 r.).

${ }^{8}$ M. Janigacz, J. Rubin (red.), Raport: Ogólnopolskie badanie zarządzania zmiana, Szkoła Zarządzania zmianą, Wrocław 2016, s. 32.

9 T. Cater, D. Pucko, Factors of effective...
} 
tylko $14 \%$ udało się ją pomyślnie wdrożyć" ${ }^{10}$. Przytoczone wyniki badań sugerują duże rozbieżności pomiędzy zaplanowaną a wdrożoną strategią organizacji. „Głównymi przyczynami niepowodzeń przedsiębiorstw we wdrażaniu oraz realizacji strategii jest nie tylko brak wyraźnie określonej wizji, niejasno sformułowana strategia, brak komunikacji wewnątrz organizacji dotyczącej przekazywania strategii, ale przede wszystkim brak jej odpowiedniego sparametryzowania, czyli niewłaściwe przełożenie strategii na cele strategiczne i operacyjne" ${ }^{11}$. Aby przyjęta strategia mogła zafunkcjonować w organizacji, musi zostać przełożona na cele i działania urzeczywistniające jej wdrożenie i realizację. Dekompozycję strategii organizacji należy rozpocząc od wyznaczenia celów strategicznych, które następnie powinny zostać uszczegółowione w celach operacyjnych. Ustalenie celów jest warunkiem koniecznym ale niewystarczającym do skutecznego wdrożenia strategii organizacji. Niezbędnym elementem jest wybór mierników (wskaźników) ${ }^{12}$ pomiaru oraz ich ciągłe monitorowanie i ocena osiąganych rezultatów. Zebrane informacje w konfrontacji z oceną sytuacji w otoczeniu pozwalają na udoskonalenie lub modyfikację przyjętych założen.

\section{CHARAKTERYSTYKA STRATEGICZNEJ KARTY WYNIKÓW}

Rozwiązaniem, które umożliwia konsekwentne definiowanie celów oraz wyznaczanie wskaźników spójnych z przyjętą strategią działania, jest strategiczna karta wyników (ang. Balanced Scorecard - BSC, określana w literaturze również jako Zrównoważona Karta Wyników). Strategiczna karta wyników jest systemem zarządzania strategicznego, wspomagającym wdrożenie strategii organizacji $1^{13}$. Zrównoważona Karta Wyników to kompleksowa metoda, która rozpatruje działalność przedsiębiorstwa jako współdziałanie perspektyw: finansowej, klientów, procesów i rozwoju pracowników ${ }^{14}$. Istota strategicznej karty wyników polega na dekompozycji strategii w obszarze czterech podstawowych perspektyw, przy czym każda z perspektyw ma taki sam priorytet. Poszczególne perspektywy odzwierciedlają logikę kreowania wartości; punktem wyjścia w kreowaniu wartości przedsiębiorstwa jest rozwój wewnętrzny ${ }^{15}$. Zatem osiągnięcie celów z obszaru rozwoju pracowników powinno zapewnić lepszą realizację procesów. Doskonałość w obszarze procesów powinna skutkować zwiększonym zadowoleniem klientów, przekładającym się na sukces finansowy przedsiębiorstwa. Perspektywy są powiązane ze sobą za pomocą oddziaływań przyczynowo-skutkowych. W konsekwencji problemy w jednej z perspek-

${ }^{10} \mathrm{~J}$. Radomska, Model of successful strategy execution: revising the concept. Problems of Management in the 21st Century 2014, s. 264, http://oaji.net/articles/2014/450-1420577194.pdf (dostęp: 23.12.2015 r.)

${ }_{11}$ M. Sierpińska, B. Niedbała, Controlling operacyjny w przedsiębiorstwie, Warszawa 2003, s. 311.

${ }^{12} \mathrm{~W}$ artykule, pomimo świadomości różnic terminologicznych w zakresie pojęć miernika i wskaźnika, użyto ich zamiennie w celu zwrócenia uwagi na konieczność przeprowadzenia pomiaru, pomijając kwestie związane z sposobem jego realizacji.

${ }^{13}$ R.S. Kaplan, P.D. Norton, Strategiczna karta wyników. Jak przełożyć strategię na działanie, Warszawa 2001

${ }^{14} \mathrm{http}: / /$ www.boc-group.com/pl/produkty/adoscore (dostęp: 21.01 .2016 r.).

${ }^{15}$ Sz. Cyfert, K. Krzakiewicz, Strategiczna karta wyników jako narzędzie dostosowania przedsiębiorstwa do warunków gospodarki rynkowej [w:] Doskonalenie polskich przedsiębiorstw i instytucji do wymogów gospodarki rynkowej. Zarządzanie zasobami, red. R. Rutka, Gdańsk 2003, s. 219. 
tyw znajdują odzwierciedlenie w rezultatach osiąganych w pozostałych perspektywach. W zakresie wyznaczonych perspektyw ustala się cele strategiczne i operacyjne równocześnie przypisując im mierniki, za pomocą których przeprowadza się pomiar ich skuteczności. Ocena realizacji strategii weryfikowana jest na podstawie odchyleń poziomu mierników od zaplanowanych wartości, tym samym umożliwiając pomiar wdrożenia przyjętych założeń. Balanced Scorecard spełnia równocześnie funkcję narzędzia budowy, wdrożenia i pomiaru realizacji strategii ${ }^{16}$. Zrównoważona Karta Wyników eliminuje lub ogranicza bariery hamujące implementację strategii w całej organizacji, na jej różnych poziomach. „Większość tradycyjnie wdrażanych strategii nie pozwala organizacjom na osiągnięcie odpowiedniego poziomu skuteczności tylko dlatego, że brak w nich wyraźnie zdefiniowanych powiązań pomiędzy działaniami krótko- i długoterminowymi. Strategiczna karta wyników przez system inicjatyw strategicznych pozwala na eliminację tej dysfunkcji" ${ }^{17}$.

Strategiczną kartę wyników można wdrożyć wykorzystując program ADOscore.

\section{OPIS DZIALANIA PROGRAMU ADOSCORE}

System ADOscore oferuje całościowe wsparcie informatyczne dla prawidłowej komunikacji w zakresie wdrażania strategii. Dane gromadzone i przetwarzane w systemie umożliwiają podejmowanie decyzji zarządczych spójnych z przyjętą strategią działania. Program ADOscore został stworzony na potrzeby wdrożenia Strategicznej Karty Wyników, jednocześnie umożliwiając zarządzanie skutecznością organizacji poprzez monitorowanie i ewaluację poziomu wyznaczonych mierników.

Program ADOscore bazuje na tworzeniu kolejnych modeli, zgodnie z którymi wdrażana jest strategia. Modele tworzy się po kolei w takim układzie, iż każdy poprzedni model jest bazą do tworzenia modelu następnego. Modele buduje się w odniesieniu do czterech perspektyw (finanse, klienci, procesy, kształcenie i rozwój) gwarantujących zrównoważony przegląd organizacji.

Kolejność tworzonych modeli prezentuje rys. 1.

Pierwszym modelem programu ADOscore jest model strategii. Pozwala on na udokumentowanie i zaprezentowanie wizji, misji, sloganu lub myśl przewodniej oraz strategii organizacji. Zawiera on podstawowe informacje o przyjętej strategii, która poddana dalszej analizie jest podstawą do identyfikacji inicjatyw zapewniających osiągnięcie przewagi konkurencyjnej. Zgromadzone informacje zapisuje się w modelu czynników sukcesu przyporządkowując zidentyfikowane zadania do odpowiednich perspektyw. Czynniki sukcesu w każdej z perspektyw grupuje się ze względu na podobieństwo tematyczne. Analogiczne elementy łączy się w cele strategiczne, przy czym należy pamiętać o zachowaniu równowagi w ilości definiowanych celów tak, aby była ona porównywalna w każdej z perspektyw. Pominięcie tego aspektu może wiązać się z nadmiernym wyeksponowaniem jednego obszaru, kosztem innego.

Zgodnie z zaleceniami producenta programu ADOscore następnym modułem jest model przyczynowo-skutkowy, jego podstawowym elementem są wcześniej wyłonione cele strategiczne, systematycznie uszczegóławiane w kolejnych etapach budowy strategicznej

\footnotetext{
${ }^{16}$ M. Karkula, B. Kowal, D. Kowal, Wykorzystanie pakietu Aris we wdrażaniu strategii przedsiębiorstwa górniczego węgla kamiennego, Logistyka - Nauka, „Logistyka” 2011, nr 2, s. 267-268.

17 Sz. Cyfert, Strategiczne doskonalenie architektury procesów w zarządzaniu przedsiębiorstwem, Poznań 2006, s. 70.
} 
karty wyników. Konfiguracja modelu przyczynowo-skutkowego rozpoczyna się od przetransformowania celów strategicznych z poprzedniego schematu, następnie ustala się zależności występujące pomiędzy różnymi celami we wszystkich perspektywach. W zidentyfikowanych powiązaniach określa się rodzaj i siłę wpływu jednego celu na drugi; w wariancie tym istnieje również możliwość wyznaczenia ścieżki krytycznej. Definiowanie i odwzorowanie zależności przyczynowo-skutkowych umożliwia określenie pozytywnych oddziaływań pomiędzy celami oraz ograniczeń w przypadku negatywnych relacji, jest to pomocne w ukierunkowaniu dalszych działań zapewniających skuteczną realizację strategii. Kolejną czynnością jest ustalenie celów operacyjnych dla każdego z celów strategicznych. Niewątpliwą zaletą systemu jest możliwość określenia i przypisania zasobów niezbędnych do realizacji celów. Kompletny model przyczynowo-skutkowy powinien zostać uzupełniony wskaźnikami wyznaczonymi zarówno dla wszystkich celów strategicznych, jak i operacyjnych. W systemie wskaźniki są opisywane w zakresie podstawowych parametrów takich jak: okres odniesienia, jednostka miary, rodzaj tolerancji, rodzaj ograniczenia, funkcja wskaźnika. Jednakże kluczowym parametrem są wartości planowane, które determinują ambitność, a zarazem realność osiągnięcia wyznaczonych celów. Przystępując do definiowania wskaźników warto zwrócić uwagę na ich mierzalność, w takim układzie, aby możliwa była ich parametryzacja w kolejnym modelu.

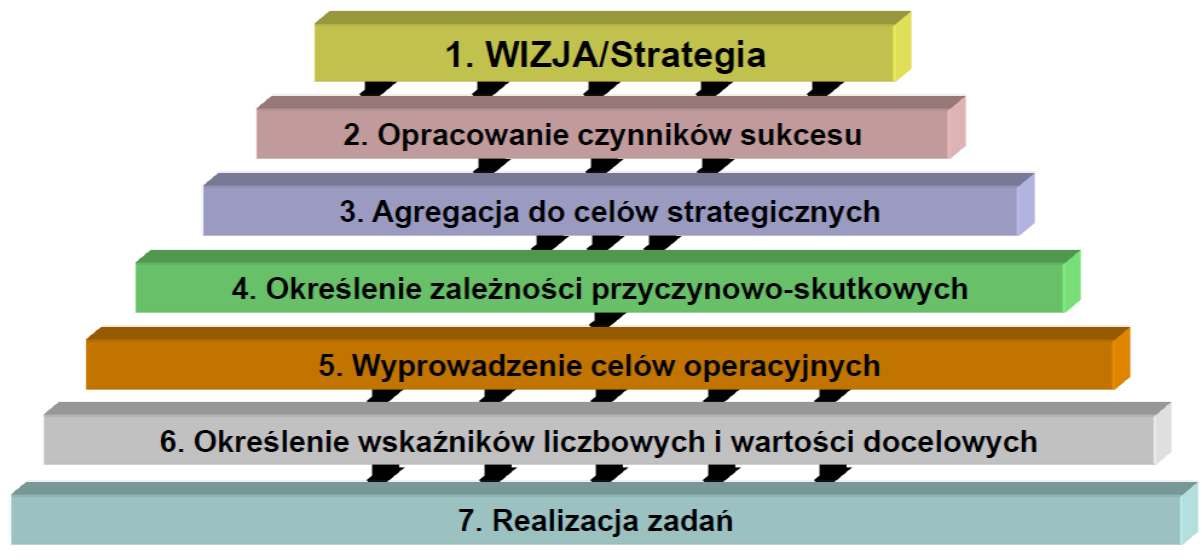

Rys. 1. Etapy tworzenia strategicznej karty wyników w programie ADOscore

Źródło: Realizacja i zarzadzanie strategiq... ze strategia do sukcesu operacyjnego!, BOC Information Technologies Consulting Sp. z o.o. http://www.boc-group.com/pl/produkty/adoscore/.

Fragment modelu przyczynowo-skutkowego dla perspektywy finansów zaprezentowano na rys. 2. Odzwierciedla on dekompozycję celów strategicznych na cele operacyjne wraz z ich opomiarowaniem. Zaprezentowany przykład obrazuje zarówno cele, które zostały zrealizowane (pojawia się przy nich jaśniejsza kropka, np. zysk z działalności gospodarczej), jak również cele problematyczne, których nie osiągnięto (odpowiada im ciemniejsza kropka, np. wartość pozyskanych środków finansowych). Model przyczynowo-skutkowy ma kluczowe znaczenie we wdrażaniu strategicznej karty wyników, ponieważ stanowi platformę integrującą pozostałe modele. 


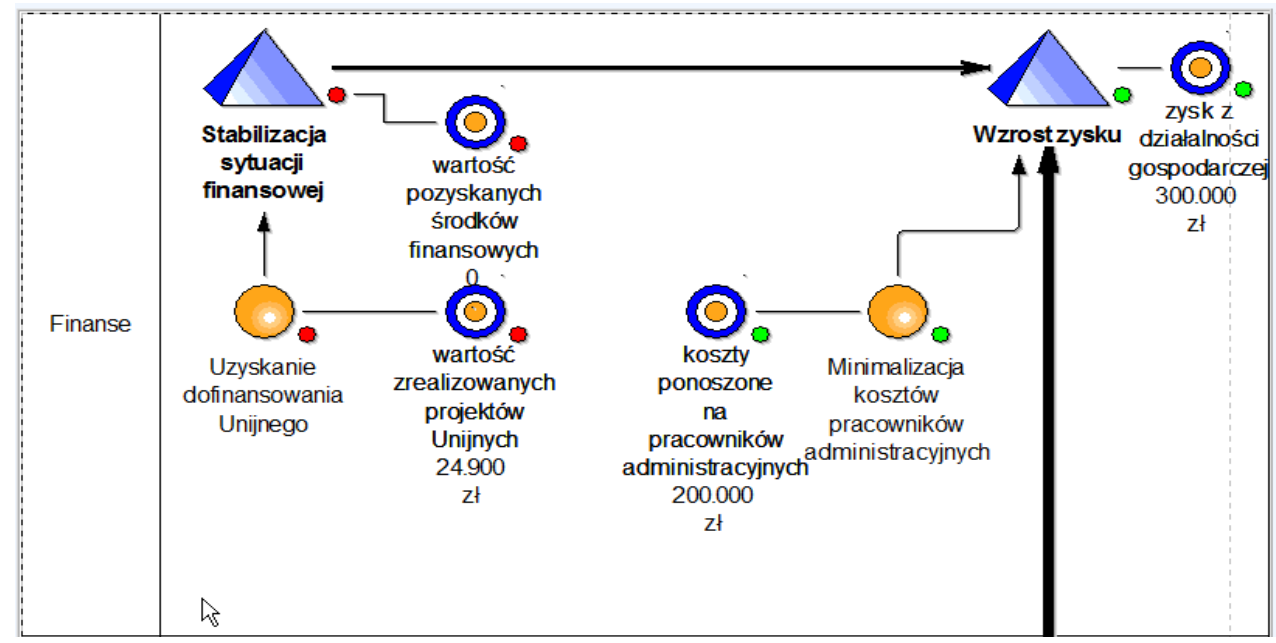

Rys. 2. Fragment modelu przyczynowo-skutkowego dla perspektywy finansów

Źródło: opracowanie własne.

Kolejnym komponentem programu ADOscore jest model wskaźników (rys. 3), który bazuje na ustaleniu sposobu obliczania każdego z mierników, poprzez opracowanie odpowiedniego wzoru matematycznego za pomocą którego przeliczane są wartości rzeczywiste.

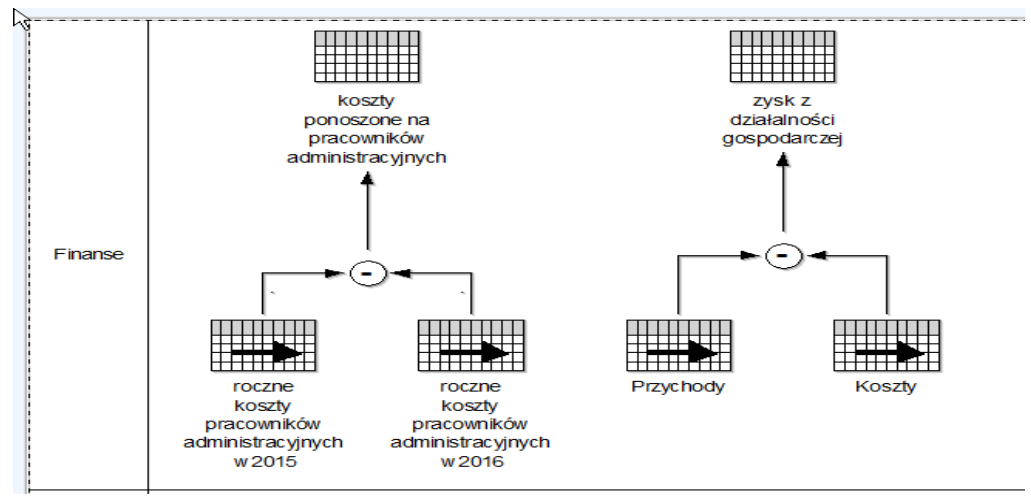

Rys. 3. Fragment modelu wskaźników dla perspektywy finansów

Źródło: opracowanie własne.

Model wskaźników wymaga uzupełnienia o model wskaźników elementarnych, w ramach którego wpisuje się rzeczywiste wartości liczbowe osiągane przez składowe wskaźników, przy czym wartości wskaźników mogą być wprowadzane ręcznie lub pobierane $\mathrm{z}$ arkuszy Excel oraz z baz danych. Ocena realizacji celów następuje na podstawie porównania wartości rzeczywistych osiąganych przez wskaźniki w odniesieniu do wartości 
planowych z uwzględnieniem ograniczeń i ustaleń zapisanych w modelu wskaźników i modelu przyczynowo-skutkowym. W analizowanym programie do weryfikacji wartości osiąganych przez wskaźniki wykorzystano zasadę sygnalizacji świetlnej. Zgodnie z regułą świateł ulicznych, czerwona kropka (na rys. 2 ciemniejsza kropka) przy wskaźniku oznacza uzyskanie nieakceptowanych wartości, zielony kolor (na rys. 2 jaśniejsza kropka) informuje o poprawności realizacji celu, natomiast żółta kropka sygnalizuje przekroczenie przez wartości wskaźnika założonych granic tolerancji ${ }^{18}$. Przyjęte $\mathrm{w}$ programie rozwiązanie ułatwia interpretację uzyskanych wyników poprzez ich jednoznaczną wizualizację. Monitorowanie wskaźników pozwala na bieżącą ocenę realizacji zarówno celów operacyjnych, jak i strategicznych, zwracając uwagę na parametry problematyczne, w przypadku których pojawiły się odchylenia od wartości planowanych. Cele, w przypadku których poziom realizacji odbiega od zaplanowanego, wymagają szczególnej uwagi, ponieważ zagrażają powodzeniu strategii. Program ADOscore ułatwia jedynie identyfikację zakłóceń, rolą osób zarządzających jest podjęcie stosownych działań zaradczych i obserwacja oraz analiza pojawiających się zmian.

Aby zrealizować określone cele strategiczne, a więc osiągnąć pożądane wartości wskaźników, należy zdefiniować działania. W programie ADOscore wykorzystuje się w tym celu model działań, w ramach którego dla każdej inicjatywy ustala się terminy rozpoczęcia i zakończenia. Działania odzwierciedlają priorytety w funkcjonowaniu organizacji w odniesieniu do przyjętej strategii.

W celu wyznaczenia odpowiedzialności oraz kompetencji za realizacje celów i działań należy stworzyć model struktury organizacyjnej, pokazujący hierarchiczne zależności pomiędzy jednostkami organizacyjnymi (działami) oraz poszczególnymi stanowiskami pracowniczymi. Podział zadań następuje poprzez przypisanie odpowiednim wykonawcom wymienionym z imienia i nazwiska odpowiedzialności za realizację wyznaczonych celów i działań. Technicznie czynność ta wiąże się z ,podpięciem” modelu struktury do modelu przyczynowo-skutkowego oraz do modułu działań.

Ostatnim modelem jest model mapy BSC. Jego zadanie polega na integracji i synchronizacji zebranych danych oraz dodaniu okresu pomiaru. Głównym założeniem tego modelu jest aktualizacja danych wraz z aktualizacją wartości rzeczywistych.

Ponadto program ADOscore umożliwia tworzenia i generowanie wewnętrznej dokumentacji firmy na bazie zebranych informacji. Zarówno wizualna ocena stopnia realizacji wyznaczonych celów, jak i możliwość raportowania uzyskanych efektów przyczyniają się do skutecznego komunikowania strategii oraz podejmowania decyzji zarządczych na podstawie wiarygodnych danych.

\section{ZALETY PROGRAMU ADOSCORE W OBSZARZE WSPOMAGANIA PODEJMOWANIA DECYZJI I KSZTALTOWANIA STRATEGII}

Producent programu ADOscore zaproponował wiele ciekawych rozwiązań ułatwiających implementację strategii. Należy do nich zaliczyć:

- zapewnienie przełożenia założeń strategicznych na poziom celów strategicznych,

- jednoznaczne i czytelne kaskadowanie celów strategicznych na niższe poziomy zarządcze,

18 A. Gębczyńska, Procesowe zarządzanie jakościa z wykorzystanie programu ADONIS [w:] Wielowymiarowość systemów zarządzania, red. M. Giemza, T. Sikora, Kraków 2015, s. 47-60. 
- ciągłe monitorowanie stopnia realizacji celów na różnych poziomach zarządczych, a tym samym możliwość weryfikacji postępów w wdrażaniu strategii,

- zwizualizowanie za pomocą sygnalizacji świetlnej problemów w zakresie realizacji przyjętych celów,

- scalanie i zsynchronizowanie wdrożenia strategii,

- bieżące nadzorowanie i pomiar celów w odwołaniu do wartości osiągniętych przez wskaźniki,

- możliwość przypisania zasobów niezbędnych do realizacji celów strategicznych,

- wskazanie odpowiedzialności za realizację celów i działań,

- utworzenie opcji generowania aktualnej dokumentacji na temat stanu wdrożenia strategii.

Wymienione liczne zalety programu ADOscore są źródłem wiarygodnych danych uzyskanych z porównania zaplanowanych wartości z ich rzeczywistym poziomem osiąganym w różnych przedziałach czasowych. Wizualna prezentacja poziomu wdrożenia strategii ułatwia interpretację uzyskanych wyników i poznanie mechanizmów towarzyszących powstaniu niezgodności lub nieskuteczności. Jednocześnie czytelność i synchronizacja wykorzystywanych modeli poprawia komunikację i motywację pracowników. Wykorzystanie programu ADOscore stwarza pracownikom szanse na zapoznanie się z swoimi celami oraz możliwość bieżącego obserwowania zmian powstałych w wyniku podjęcia konkretnych działan. Weryfikacja poziomu skuteczności celów wpływa na lepsze zrozumienie przyjętej strategii i zidentyfikowanie czynników determinujących uzyskanie sukcesu. Jednoznaczne przypisanie odpowiedzialności za realizację celów eliminuje konflikty personalne i organizacyjne, usprawniając funkcjonowanie przedsiębiorstwa. Zaproponowana w ADOscore postać tworzenia dokumentacji znacznie redukuje czas potrzebny na jej opracowanie, wdrożenie i publikację. Warto podkreślić, iż przyjęty w ramach programu ADOscore system pomiaru i monitoringu realizacji celów pozwala na ocenę skuteczności organizacji na różnych jej poziomach.

Program ADOscore może być istotnym wparciem dla kadry menedżerskiej w podejmowaniu decyzji, pod warunkiem bieżącej weryfikacji uzyskanych efektów w połączeniu z aktywnym modelowaniem przyjętych rozwiązań. Wykorzystanie programu ADOscore przynosi wymierne rezultaty, jeśli we wdrażanie strategicznej karty wyników zaangażowani będą wszyscy pracownicy, którzy regularnie otrzymają feed back na temat skuteczności podejmowanych działań, a ich zaangażowanie znajdzie odzwierciedlenie w systemie motywacyjnym. Monitorowanie poziomu realizacji strategii ma być również bodźcem to ewentualnych modyfikacji wynikających z konieczności dostosowania do zmiennych wymagań rynkowych.

Podstawą stabilnego rozwoju organizacji jest prawidłowa komunikacja strategii oraz przejrzyste i zrozumiałe dla wszystkich mechanizmy sterowania. Na znaczeniu zyskuje także dostępność właściwie przygotowanych danych zarządczych, na podstawie których podejmowane są kluczowe decyzje. Prawdopodobieństwo uzyskania powyższych korzyści wzrasta przy wdrożeniu programów informatycznych wspomagających implementację strategii. Przytoczona w artykule argumentacja powinna przekonać do skorzystania z możliwości, jakie stwarza program ADOscore w zakresie wspomagania podejmowania decyzji i kształtowania strategii z wykorzystaniem strategicznej karty wyników. 


\section{PODSUMOWANIE}

Strategia jest kluczowym dokumentem warunkującym rozwój przedsiębiorstwa w wyznaczonym kierunku. Liczne problemy ze skutecznym wdrażaniem strategii wymagają odpowiednich rozwiązań metodologicznych wspieranych rozwiązaniami informatycznymi. Właściwy system informatyczny pozwala zintegrować i synchronizować wyznaczone cele i skutecznie nimi zarządzać z perspektywy uzyskania zaplanowanych wyników. W obszarze wdrażania strategii zastosowanie znajduje strategiczna karta wyników, a narzędziem wspomagającym jej implementację jest programu ADOscore. Modele wykorzystywane w ramach programu ADOscore bazują na zintegrowanych bazach danych, co pozwala na ujednolicenie i kontrolę informacji przetwarzanych w różnych wariantach pakietu. Przyjęte rozwiązania wpływają na poprawę komunikacji, jak i przyspieszają przepływ informacji wewnątrz przedsiębiorstwa. Opisany w artykule system informatyczny umożliwia rejestrowanie, przesyłanie, przechowywanie, przetwarzanie, jak również prezentowanie zebranych danych, stwarzając możliwość do analizy, oceny i modelowania przyjętych rozwiązań. Jak wykazały rozważania zaprezentowane w niniejszym artykule, program ADOscore pozwala na kształtowanie strategii oraz wspomaga podejmowanie decyzji.

\section{LITERATURA}

[1] Burlton R., Delivery Business Strategy Through Process Management, Handbook on Business Process Management 2, 2015. Strategic Alignment, Governance, People and Culture, http://www.springer.com/978-3-642-45102-7.

[2] Cater T., Pucko D., Factors of effective strategy implementation: empirical evidence from Slovenian business practice, J East Eur Manag Stud 15(3), 2010, http://www.jstor.org/stable/23281679.

[3] Cobbold I., Lawrie G., Why do only one third of UK companies achieve strategic success?, 2001, 2GC Ltd. http://v7a.2gc.org/files/resources/2GC-WP-UKCoStratSuc090311.pdf.

[4] Cyfert Sz., Strategiczne doskonalenie architektury procesów w zarządzaniu przedsiębiorstwem, Akademia Ekonomiczna, Poznań 2006.

[5] Cyfert Sz., Krzakiewicz K., Strategiczna karta wyników jako narzędzie dostosowania przedsiębiorstwa do warunków gospodarki rynkowej [w:] Dostosowanie polskich przedsiębiorstw i instytucji do wymogów gospodarki rynkowej, red. R. Rutka, Wyd. Uniwersytetu Gdańskiego, Sopot 2003, s. 215-224.

[6] Gębczyńska A., Procesowe zarządzanie jakościa z wykorzystanie programu ADONIS [w:] Wielowymiarowość systemów zarzadzania, red. M. Giemza, T. Sikora, Uniwersytet Ekonomiczny w Krakowie, Kraków 2015, s. 47-60.

[7] Gierszewska G., Olszewska B., Skonieczny J., Zarządzanie strategiczne dla inżynierów, Polskie Wydawnictwo Ekonomiczne, Warszawa 2013.

[8] Janigacz M., Rubin J. (red.), Raport: Ogólnopolskie badanie zarządzania zmiana, Szkoła Zarządzania Zmianą, Wrocław 2016.

[9] Kaleta A., Realizacja strategii, Polskie Wydawnictwo Ekonomiczne, Wrocław 2013.

[10] Kaplan R.S., Norton D.P., Strategiczna karta wyników. Jak przełożý strategię na działanie, WN PWN, Warszawa 2001. 
[11] Karkula M., Kowal B., Kowal D., Wykorzystanie pakietu Aris we wdrażaniu strategii przedsiębiorstwa górniczego węgla kamiennego, Logistyka - nauka, „Logistyka” 2/2011, s. 267-268.

[12] Radomska J., Model of successful strategy execution: revising the concept, Problems of Management in the 21st Century, 2014, http://oaji.net/articles/2014/450-1420577194.pdf.

[13] Realizacja i zarzadzanie strategia... ze strategia do sukcesu operacyjnego!, BOC Information Technologies Consulting Sp. z o.o. http://www.boc-group.com/pl/produkty/ adoscore/.

[14] Sierpińska M., Niedbała B., Controlling operacyjny $w$ przedsiębiorstwie, WN PWN, Warszawa 2003.

[15] Stabryła A., Zarzadzanie strategiczne $w$ teorii i praktyce firmy, Polskie Wydawnictwo Naukowe, Warszawa-Kraków 2002.

\section{USING ADOSCORE AS A PROGRAM TO SUPPORT DECISION MAKING AND STRATEGY DEVELOPMENT}

It is for the instability of environment that an organization is required to constantly develop in line with expectations of its customers and other stakeholders. The development orientation it has assumed must conform with the organisation's vision and should be reflected in the corporate strategy comprising both the objectives and the actions contributing to an accomplishment of the success pursued. The implementation and measurement of the strategy execution are the reasons why one should use a methodology supporting the implementation. However, the strategy implementation efficiency is heavily dependent on the ability to utilise the available IT techniques. The foregoing concept became the premise for analysing ADOscore in order to identify the potential benefits the program offers in terms of decision making and strategy development support. For this purpose, the opening section of the article introduces the very notion of strategy, referring to the complexity of its implementation process and restrictions limiting strategy deployment. In subsequent paragraphs, both the assumptions and the idea behind one of methods used to implement the strategy have been discussed. For this purpose, the Strategic Scorecard has been addressed, since it is the foundation on which ADOscore was developed. Further on, in the article the program itself has been analyzed, particularly highlighting the practical aspects of its application and presenting sample models. Having examined the program in detail and analyzed its functionality, one could identify its advantages in the area of decision making and strategy development.

Keywords: ADOscore program, strategy, Balanced Scorecard, advantages of the program, strategic management, mission of the organization.

\section{DOI: 10.7862/rz.2017.mmr.3}

Tekst złożono $w$ redakcji: listopad $2016 r$. Przyjęto do druku: marzec 2017 r. 